haemorrhagic lesion, and the possibility that the primary event may have been ischaemic or thromboembolic requires investigation.

We suggest that intracerebral damage in neonatal isoimmune thrombocytopenic purpura may arise in three different ways. Perinatal haemorrhage may occur as a result of birth trauma. Spontaneous haemorrhage may occur prenatally secondary to severe thrombocytopenia (as in case 1). Finally, earlier prenatal lesions may occur giving rise to the neurological features we have described.

The relative incidence of these lesions is unknown; our experience with five cases suggests that prenatal lesions may be more common than previously thought. Further investigation of the mechanism of the earlier prenatal lesions is required as there are important implications for obstetric management. Regular antenatal ultrasound screening in pregnancies thought to be affected may give further information about the nature and timing of events.

Because the purpura is transient, neonatal isoimmune thrombocytopenic purpura may remain undiagnosed in the neonatal period. Some unexplained cases of porencephaly may therefore be the result of prenatal damage in neonatal isoimmune thrombocytopenic purpura (case 5). We looked at a further five children with unexplained porencephaly and carried out platelet typing of mother and child; in no case was there evidence of platelet incompatibility. Nevertheless, neonatal isoimmune thrombocytopenic purpura should be considered as a possible diagnosis in unexplained porencephaly, particularly if it is associated with optic hypoplasia.

In conclusion, prenatal intracerebral lesions occur in association with neonatal isoimmune thrombocytopenic purpura and give rise to a characteristic pattern of neurological abnormality, including optic hypoplasia. Further clarification of the mechanism of these lesions is required.

We thank Dr R Crawford and the Blood Transfusion Service, Law Hospital for their help.

\section{References}

' Patriarco M, Yeh S. Immunological thrombocytopenia in pregnancy. Obstet Gynecol Surv 1986;41:661-71.

2 Zalneraitis EL, Young RSK, Krishnamoorthy KS. Intracerebral hemorrhage in utero as a complication of isoimmune thrombocytopenia. J Pediatr 1979;95:611-4.

3 Magny JF, Vial M, Bessis R, et al. Hémorragie cérébrale anténatale et incompatibilité plaquettaire foeto-maternelle. Arch Fr Pediatr 1984;41:711-2.

${ }^{4}$ Morales WJ, Stroup M. Intracranial hemorrhage in utero due to isoimmune neonatal thrombocytopenia. Obstet Gynecol 1985;65:20s-1.

5 De Vries LS, Connell J, Bydder GM, et al. Recurrent intracranial haemorrhages in utero in an infant with alloimmune thrombocytopenia. Case report. Br J Obstet Gynaecol 1988;95:299-302.

6 Friedman JM, Aster RH. Neonatal alloimmune thrombocytopenic purpura and congenital porencephaly in two siblings associated with a 'new' maternal antiplatelet antibody. Blood 1985;65:1412-5.

Correspondence to Dr JE Davidson, Department of Pathology, Western Infirmary, Glasgow G11 6NT.

Accepted 25 January 1989

\title{
Flecainide toxicity
}

\section{G A B RUSSELL AND R P MARTIN}

Department of Paediatric Cardiology, Royal Liverpool Children's Hospital

SUMmary Flecainide toxicity occurred in an infant being treated for refractory atrioventricular re-entry tachycardia. Ventricular tachycardia developed when dextrose was substituted for milk feeds. We believe that milk was interfering with the absorption of flecainide, and so a high serum concentration developed when milk feeds were stopped.

Flecainide acetate is a comparatively new drug for the treatment of supraventricular and ventricular arrhythmias. Early clinical experience in infants and children has shown that it is effective and well tolerated. $^{12}$

\section{Case report}

A baby boy was born at 34 weeks' gestation after an apparently uncomplicated pregnancy. He was hydropic at birth, weighing $3100 \mathrm{~g}$ (>90th centile). Resuscitation with endotracheal intubation was required, and mechanical ventilation was continued for three days. After extubation he remained cyanosed and a hyperoxic test confirmed the presence of an appreciable right to left shunt. Standard investigations did not identify a cause for the hydrops fetalis, and he was referred for cardiological assessment.

On transfer to our hospital at 6 days of age he weighed $2100 \mathrm{~g}$ and was no longer hydropic. He 
appeared cyanosed on $30 \%$ oxygen, and was mildly tachypnoeic. There was a grade $2 / 6$ midsystolic murmur, maximal at the left fourth intercostal space. The liver was palpable $3 \mathrm{~cm}$, and the spleen $1 \mathrm{~cm}$, below the costal margin.

The electrocardiogram showed sinus rhythm with no evidence of pre-excitation. A radiograph of the chest showed mild cardiomegaly. Cross sectional echocardiography identified an atrial septal defect, with dominant right to left shunting on contrast and Doppler examination.

The pulmonary venous connection was uncertain so cardiac catheterisation was carried out to exclude total anomalous pulmonary venous connection. A pulmonary arteriogram, however, did establish that the pulmonary veins connected normally to the left atrium. There was appreciable pulmonary hypertension and a right to left shunt at atrial level. It is likely that this was associated with persistent pulmonary hypertension of the newborn.

Cardiac catheterisation was complicated by an episode of supraventricular tachycardia. Direct current cardioversion restored sinus rhythm but several further episodes of tachycardia occurred during the next 24 hours. An electrocardiogram taken during an episode of tachycardia showed the features of atrioventricular re-entry tachycardia. The tachycardia was initially treated by direct current cardioversion and digitalisation, but as the episodes continued flecainide $(0 \cdot 5-2 \cdot 0 \mathrm{mg} / \mathrm{kg})$ was given intravenously. Oral flecainide was started at a dose of $2 \mathrm{mg} / \mathrm{kg}$ in divided doses, and increased while serum concentrations were closely monitored. There was a reduction in the frequency of the episodes of tachycardia as the oral dose of flecainide was increased over a period of two to three weeks. It was noted that a high dose of flecainide was required to gain control of the tachycardia and achieve adequate serum concentrations. The normal recommended dose of flecainide is $2-10 \mathrm{mg} / \mathrm{kg}$ in divided doses, but in this patient a total dose of 30 $\mathrm{mg} / \mathrm{kg}$ did not completely control the tachycardia.

It was suspected that inadequate absorption might account for the poor clinical response, as the tachycardia responded consistently to flecainide given intravenously. To assess this, the serum flecainide concentration was measured two, five, and eight hours after $25 \mathrm{mg}$ of flecainide had been given orally (table). The dose at the time was $25 \mathrm{mg}$ every eight hours $(30 \mathrm{mg} / \mathrm{kg} /$ day $)$. As the serum concentrations were in the lower part of the reference range, the dose was increased further to $25 \mathrm{mg}$ every six hours $(40 \mathrm{mg} / \mathrm{kg} / \mathrm{day})$. This abolished the tachycardia for eight days, but there was concern about the high dose required.

It was considered possible that milk might be
Table 1 Serum flecainide concentrations

\begin{tabular}{|c|c|c|c|}
\hline \multirow[t]{2}{*}{ Dose of flecainide (mg) } & \multicolumn{3}{|c|}{$\begin{array}{l}\text { Serum flecainide } \\
\text { concentrations ( } \mu \text { gll)* after } \\
\text { administration (hours) }\end{array}$} \\
\hline & 2 & 5 & 8 \\
\hline $\begin{array}{l}25 \mathrm{mg} \text { Orally every } \\
\text { eight hours }(30 \mathrm{mg} / \mathrm{kg} / \text { day }) \\
\text { with milk feeds }\end{array}$ & 188 & 203 & 519 \\
\hline $\begin{array}{l}25 \mathrm{mg} \text { Orally } \\
\text { every six hours } \\
\text { ( } 40 \mathrm{mg} / \mathrm{kg} / \mathrm{day}) \text { with } \\
\text { milk feeds }\end{array}$ & 990 & - & - \\
\hline $\begin{array}{l}25 \mathrm{mg} \text { Orally } \\
\text { every six hours } \\
(40 \mathrm{mg} / \mathrm{kg} / \text { day }) \text { dextrose } \\
\text { feeds only for } 24 \text { hours }\end{array}$ & 1824 & - & - \\
\hline
\end{tabular}

${ }^{*}$ Reference range $400-1000 \mu \mathrm{g} / \mathrm{l}$.

interfering with absorption of flecainide as there was no clinical evidence of malabsorption. This was evaluated by measuring serum flecainide concentrations before and after a 24 hour period of receiving $5 \%$ glucose feeds alone (see table). At the end of the 24 hour period he developed ventricular tachycardia. This was present intermittently for the next 60 minutes, but as the patient remained haemodynamically stable no additional treatment was given. The oral flecainide was stopped and milk feeds restarted.

The supraventricular tachycardia recurred 24 hours after the flecainide had been stopped. Treatment with a combination of digoxin and propranolol, and digoxin and disopyramide, was unsuccessful. Eventually he was given amiodarone orally $(3 \mathrm{mg} / \mathrm{kg}$ three times daily) and when therapeutic serum concentrations were achieved the tachycardia was controlled. During six months of outpatient follow up, he has remained free of tachycardia.

\section{Discussion}

This case shows that milk may interfere with the absorption of flecainide given orally in early infancy, and it is possible for flecainide toxicity to occur on withdrawal of milk feeding. Clinical experience in the use of flecainide in the management of childhood tachyarrhythmias is increasing. There is, however, little information on its use in infancy. The pharmacology of flecainide has been studied in adults $^{3}$ and extrapolation to infancy may not be accurate.

Flecainide has a proarrhythmic effect and this may occur within the 'therapeutic range'. ${ }^{45}$ Ven- 
tricular tachycardia has previously been noted with serum concentrations of greater than $1000 \mu \mathrm{g} / \mathrm{l}$, and occasionally during intravenous administration. ${ }^{1}$ This patient developed ventricular tachycardia when a toxic serum flecainide concentration was achieved. It is likely that the ventricular tachycardia was a direct result of that serum concentration. The occurrence of ventricular tachycardia is of concern because of the association between sudden death and such arrhythmias.

Many cardiac units are using flecainide for first or second line treatment of supraventricular tachycardia, particularly in overt Wolff-Parkinson-White syndrome. Milk has not been reported to interfere with flecainide absorption in other children, but Wren and Campbell noted one patient (1 year old) who required a large oral dose $(22.5 \mathrm{mg} / \mathrm{kg} /$ day) to achieve a therapeutic serum concentration. ${ }^{6}$ It is possible that this may be a common phenomenon and merits further investigation. It becomes of particular importance in early infancy when the diet is milk alone. We recommend that milk fed infants on high doses of flecainide should have the dose reduced when milk is reduced or stopped-for example, during an attack of gastroenteritis, or when weaning. Close monitoring of plasma concentrations is likely to be helpful in the management of such patients.

\footnotetext{
References

1 Till JA, Rowland E, Ward DE. Treatment of refractory supraventricular arrhythmias with flecainide acetate. Arch Dis Child 1987;62:247-52.

2 Ward DE, Jones S, Shinebourne EA. Use of flecainide for refractory junctional tachycardias in children with the WolffParkinson-White Syndrome. Am J Cardiol 1986;57:787-90.

${ }^{3}$ Conrad GJ, Ober RE. Metabolism of flecainide. Am J Cardiol 1984;53:41-51B.

${ }^{4}$ Morganroth J, Horowitz LN. Flecainide: its proarrhythmic effect and expected changes on the surface electrocardiogram. Am J Cardiol 1984;53:89-94B.

5 Nathan AW, Hellestrand KJ, Bexton RS, Banim SO, Spurreil RAJ, Camm AJ. Proarrhythmic effects of the new antiarrhythmic agent flecainide acetate. Am Heart J 1984;107:222-8.

6 Wren C, Campbell RWF. The response of paediatric arrhythmias to intravenous and oral flecainide. Br Heart J 1987;57: $171-5$.
}

Correspondence to Dr RP Martin, Department of Paediatric Cardiology, Royal Hospital for Sick Children, St Michael's Hill, Bristol BS2 8BJ.

Accepted 3 January 1989

\title{
Phycomycotic abscesses in a preterm infant
}

\author{
P C NG AND P R F DEAR
}

Department of Paediatrics and Child Health, University of Leeds, St James's University Hospital

SUMMARY We report a case of neonatal infection with rhizopus, one of the Mucoraceae family. Human infection is rare but the mortality is high without prompt, correct treatment. The infant had a simultaneous candida septicaemia secondary to colonisation of a central venous line. Serial C reactive protein estimations are valuable in monitoring treatment.

Fungal skin abscesses (usually caused by Candida spp) are common among preterm babies, especially those receiving intensive care. ${ }^{1}$ We describe an abscess caused by an unusual pathogen, rhizopus, which, although well documented as a cause of serious infection in immunocompromised adults and children, ${ }^{2-4}$ has rarely been described in the newborn. ${ }^{3}$ The case also teaches an important lesson about the diagnosis and treatment of infection with multiple organisms.

\section{Case report}

A baby boy was born by emergency caesarean section (because of antepartum haemorrhage) at 26 weeks' gestation, weighing $1100 \mathrm{~g}$. Mild respiratory distress syndrome was diagnosed and the baby was initially managed in headbox oxygen. On the fourth day of life he required positive pressure ventilation and was transferred to the neonatal intensive care unit at this hospital.

On arrival his blood glucose concentration was 28 $\mathrm{mmol} / \mathrm{l}$, he had a metabolic acidosis, and was clinically dehydrated. Despite prompt rehydration he developed acute renal failure due to tubular necrosis. Peritoneal dialysis was needed for nine days until his renal function recovered. During dialysis coagulase negative staphylococcal peritonitis developed, but he was successfully treated with a combination of parenteral and intraperitoneal vancomycin. A Broviac catheter for venous access was sited in the internal jugular vein. 